\title{
DOSTAVA U ZEMLJIŠNOKNJIŽNOM POSTUPKU
}

\author{
Zinka Bulka, dipl. iur.*
}

\author{
UDK 347.235.11(497.5) \\ https://doi.org/10.30925/zpfsr.42.2.13 \\ Ur.: 14. siječnja 2021. \\ Pr.: 22. lipnja 2021. \\ Pregledni rad
}

\begin{abstract}
Sažetak
Uradu se daje prikaz odredbi Zakona o zemljišnim knjigama koje uređuju dostavu pismena u navedenom postupku. Ukazuje se na posebnost zemljišnoknjižnoga postupka jer se provedba upisa obavlja prije pravomoćnosti rješenja o upisu pa i prije njegove dostave strankama. Pažnja je posvećena dostavi odluka (rješenje) u zemljišnoknjižnom postupku, dostavi poziva i ostalih pismena te na manjkavosti Zakona u tom dijelu. Upozoreno je na novine koje donosi elektronička dostava te posebno na pravne posljedice uredne/neuredne dostave. Posebna je pažnja dana dostavi izvan Republike Hrvatske $i$ to s naglaskom na dostavu u države članice Europske unije, ali i na dostavu u ostale države, posebno susjedne. Sobzirom na aktualnost Brexita upozoreno je i na koji način će se vršiti dostava u Ujedinjeno Kraljevstvo.
\end{abstract}

Ključne riječi: dostava; vrste $i$ važnost dostave; adresa primatelja; dostava $u$ inozemstvo.

\section{1. $U V O D$}

Dostava je zakonom uređen postupak što ga poduzima sud ili drugo tijelo radi predaje pismena primatelju kako bi se upoznao s njegovim sadržajem. U sudskim postupcima dostava je aktivnost suda, a svrha je osigurati pouzdan sustav obavještavanja primatelja o sadržaju pismena koja im se upućuju. Dostavom se omogućuje stranci, odnosno osobi kojoj se pismeno dostavlja saznati za sadržaj pismena koje mu se dostavlja, kako bi u tom postupku mogao slobodno i pravodobno poduzimati procesne radnje koje mu stoje na raspolaganju. Svaka stranka mora biti obaviještena o svemu što je ključno da bi mogla primjereno i učinkovito sudjelovati u postupku.

I u zemljišnoknjižnom postupku, obavješćivanjem o poduzetim radnjama i odlukama suda te o mogućnosti ulaganja pravnih lijekova štite se subjektivna prava stranaka i ostalih zainteresiranih osoba u postupku. No taj postupak ima svoje osobitosti i to kako u postupanju suda prije ostvarivanja tih prava stranaka i u

* Zinka Bulka, dipl. iur., sutkinja Županijskog suda u Velikoj Gorici; zinka.bulka@svg. pravosudje.hr. ORCID: https://orcid.org/0000-0002-7120-4313. 
omogućavanju njihove učinkovite zaštite $u$ žalbenom postupku kao i podnošenjem posebnih tužbi kojima se štite ta prava. Pri tome zemljišnoknjižni sud postupa po pravilima Zakona o zemljišnim knjigama (dalje: ZKK) ${ }^{1}$ i izvanparničnog postupka, a podredno i parničnog postupka, ${ }^{2}$ te ZZK sadrži odredbe materijalno pravne prirode, ali i procesne odredbe.

\section{DOSTAVA ODLUKA U ZEMLJIŠNOKNJIŽNOM POSTUPKU}

Vezano uz dostavu u zemljišnoknjižnom postupku najprije će se reći nešto o dostavi odluka u zemljišnoknjižnom postupku, o tome na koju adresu se vrši dostava, ukazat će se na razliku dostave fizičkim osobama i dostave pravnim osobama, o postupanju suda kada dostavu nije moguće izvršiti na adresu iz prijedloga. Također će se ukazati na probleme vezane uz dostavu poziva na ročišta koja se održavaju kako u redovnom tako i u posebnim zemljišnoknjižnim postupcima.

\subsection{Kome i kada se dostavljaju odluke u zemljišnoknjižnom postupku}

Odluke u zemljišnoknjižnom postupku donose se u obliku rješenja. Rješenje će se u zemljišnoknjižnom postupku dostaviti predlagatelju ili njegovom punomoćniku i osobama na čijoj se nekretnini stječe knjižno pravo i čija se knjižna prava prenose, ili opterećuju, ograničavaju ili ukidaju kao i osobi protiv koje je provedena zabilježba. ${ }^{3}$ Stoga valja ukazati da kada zemljišnoknjižni sud udovoljava prijedlogu predlagatelja i mijenja zemljišnoknjižno stanje u korist predlagatelja, a na štetu nekih drugih ranijih ovlaštenika knjižnih prava čija se prava prenose, opterećuju, ograničavaju ili ukidaju, takvo rješenje mora dostaviti i tim osobama.

Rješenje kojim se dopušta potpuno ili djelomično brisanje nekog upisa dostavlja se svim osobama koje imaju uknjižena ili predbilježena prava na onom pravu čije se potpuno ili djelomično brisanje dopušta. Rješenje o uknjižbi ili predbilježbi kojim se zalažu ili ustupaju već upisana prava trećih osoba dostavlja se i vlasniku nekretnine. Rješenje o uknjižbi ili predbilježbi vlasništva dostavlja se i založnim vjerovnicima. Rješenje o ispravku upisa dostavit će se osobama kojima se dostavlja i rješenje o upisu. Rješenja suda o upisima povezanim sa stjecanjem nekretnina i prava na nekretninama koja podliježu poreznoj obvezi, kao i rješenja kojima se zasniva ili prestaje založno pravo po službenoj dužnosti dostavljaju se ispostavi Porezne uprave na području na kojem se nalazi nekretnina.

Kada se odbija predloženi upis, odnosno kada se prijedlog odbacuje pa se ne mijenjaju, ne opterećuju, ne ukidaju i ne ograničavaju ničija knjižna prava takvo se rješenje mora dostaviti samo predlagatelju.

Rješenje o upisu dostavlja se nakon što je provedeno. ${ }^{4}$ To je posebnost zemljišnoknjižnog postupka da sud odlučuje o prijedlogu stranke, te svoju odluku provodi u zemljišnim knjigama. Dostava odluke predlagatelju, kao i svim ostalim

1 Zakon o zemljišnim knjigama, Narodne novine, br. 63/19.

2 Čl. 99. st.2. ZZK-a.

3 Čl. 138. st. 1. ZZK-a.

4 Čl. 138. st. 2. ZZK-a propisano je da se rješenje o upisu dostavlja nakon njegove provedbe. 
osobama kojima je potrebno dostaviti odluku, provodi se nakon provedbe rješenja suda.

\subsection{Adresa na koju se vrši dostava}

Dostava se obavlja na adresu koja je navedena u prijedlogu. Prijedlog mora sadržavati ime, prezime, adresu i osobni identifikacijski broj osobe u čiju korist treba provesti upis i osobe protiv koje se provodi upis, ali i osobe koje treba obavijestiti o rješenju. Time se štite prava stranaka povezana s dostavom jer je predlagatelj taj koji, da bi mu prijedlog bio procesno dopušten, mora u prijedlogu navesti sve podatke koji su nužni da bi se dostava uredno obavila. Ako prijedlog predlagatelja nema sve potrebno da bi se dostava mogla uredno izvršiti takav se prijedlog odbacuje.

\subsection{Dostava fizičkim osobama}

Rješenja u zemljišnoknjižnom postupku dostavljaju se osobno, odnosno pismeno se mora uručiti osobno osobi na koju je naslovljeno. ZZK-a ne obuhvaća odredbe o tome što se smatra osobnom dostavom pa se stoga primjenjuju odredbe Zakona o izvanparničnom postupku i Zakona o parničnom postupku (dalje: ZPP), ${ }^{5}$ ali samo u onom dijelu u kojem to nije propisano ZZK-om.

Ako se primatelj ne zatekne na adresi iz prijedloga, ne primjenjuju se odredbe ZPP-a vezano za osobnu dostavu budući da ZZK-a obuhvaća odredbe o tome kako postupiti u takvoj situaciji. Kad se osoba kojoj se dostavlja pismeno ne zatekne na adresi, dostavljač će ostaviti pismeno kod punoljetne osobe zatečene na adresi ili u poštanski sandučić ili u pretinac, a na dostavnici će naznačiti dan i način dostave. Smatra se da je dostava izvršena protekom roka od 30 dana od dana dostave pismena kod punoljetne osobe zatečene na adresi ili u poštanski sandučić ili u pretinac.

Ako stranka ima punomoćnika, dostava se obavlja punomoćniku stranke, a ne stranci osobno, a pritom valja primijeniti odredbe ZPP-a povezane s osobnom dostavom. ${ }^{6}$

U prijedlogu za knjižni upis predlagatelj može naznačiti opunomoćenika za dostavu pismena s njegovom točnom adresom za dostavu. Dostava pismena tada se obavlja punomoćniku za primanje pismena, neovisno o tome ima li predlagatelj inače

5 Zakon o parničnom postupku, Narodne novine, br. 53/91., 91/92., 112/99., 88/01., 117/03., 2/07., 84/08., 96/08., 123/08., 57/11., 148/11., 25/13., 28/13., 89/14. i 70/19.

6 ZZK-a ne obuhvaća odredbe povezane s dostavom kada stranka ima punomoćnika. Stoga, sukladno čl. 99. st. 2. ZZK-a dostava se obavlja primjenom odredbi izvanparničnog postupka. Kako još uvijek nemamo Zakon o sudskom izvanparničnom postupku to se primjenjuju odredbe Zakona o sudskom vanparničnom postupku od 24. srpnja 1934., Službene novine, br. 175XLV, koji se Zakon u Republici Hrvatskoj primjenjuje sukladno sa Zakonom o načinu primjene pravnih propisa donesenih prije 6. travnja 1941. godine, Narodne novine, br. 73/91. (dalje: ZNP) i to kao pravna pravila, jer se pravna pravila sadržana u Zakonu o sudskom vanparničnom postupku od 24. srpnja 1934. primjenjuju na odnose koji nisu uređeni važećim propisima Republike Hrvatske ako su u skladu s Ustavom i zakonima Republike Hrvatske (čl. 2. ZNP-a). Čl. 8. § 1. Zakona o sudskom vanparničnom postupku propisano je da se u izvanvanparničnim stvarima dostavljanje vrši po službenoj dužnosti na način kako to propisuje građanski postupak. Stoga se primjenjuju odredbe čl. 138. ZPP-a. 
punomoćnika. Dostava se smatra izvršenom dostavom punomoćniku za primanje pismena .

\subsection{1. Što ako nije moguće izvršiti dostavu}

Kad dostavljač pri pokušaju dostave dozna razloge zbog kojih pismeno nije moguće uručiti naslovljenoj osobi (npr. „nepoznat”, „odselio”, ,umro” i sl.), pismeno će vratiti sudu uz naznaku razloga zbog kojih ga nije moguće dostaviti. Ako je pismeno vraćeno s naznakom „nepoznat“ ili „odselio”, sud će pribaviti podatak iz evidencije Ministarstva unutarnjih poslova (dalje: MUP) o adresi prebivališta, odnosno boravišta. Ako je riječ o istoj adresi na kojoj je dostava prethodno ostala bezuspješna, sud će istekom roka od 30 dana od prethodne neuspjele dostave ponovno pribaviti podatak iz evidencije MUP-a o adresi prebivališta odnosno boravišta primatelja te mu pismeno dostaviti na tu adresu. Ako ponovna dostava na adresu iz evidencije MUP-a ne uspije pismeno će se objaviti na oglasnoj ploči suda. Ako MUP obavijesti sud da nema podataka o adresi primatelja, pismeno će se objaviti na oglasnoj ploči suda.

Kad se pismeno vrati s naznakom da je primatelj pismena umro, a zemljišnoknjižni sud u roku od 60 dana od takvog saznanja nije primio obavijest o nasljednicima, pismeno će se objaviti na oglasnoj ploči suda. Smatrat će se da je dostava obavljena istekom 30 dana od dana stavljanja pismena na oglasnu ploču suda.

\subsection{Dostava pravnim osobama}

Pravnoj osobi koja je upisana u određeni sudski ili drugi upisnik dostava se obavlja na adresu navedenu u prijedlogu. Ako dostava na adresu navedenu u prijedlogu ne uspije, dostava će se obaviti na adresu sjedišta te osobe upisanu u upisniku. Ako dostava ne uspije ni na toj adresi, obavit će se stavljanjem pismena na oglasnu ploču suda. Ako je adresa upisanog sjedišta pravne osobe istovjetna adresi navedenoj u prijedlogu, dostava se neće ponoviti na tu adresu, već će se obaviti stavljanjem pismena na oglasnu ploču suda. Smatrat će se da je dostava obavljena istekom osmoga dana od dana stavljanja pismena na oglasnu ploču suda.

\subsection{Dostava u posebnim postupcima}

ZZK-a ne obuhvaća odredbe o načinu dostave u posebnim postupcima. Vezano za pojedinačno ispravni postupak propisano je da će se rješenje o otvaranju ispravnog postupka dostaviti podnositelju prijedloga, osobama iz čijeg se upisa nedvojbeno zaključuje da bi dostava bila moguća te osobama koje su zahtijevale upise u zemljišnu knjigu nakon zabilježbe otvaranja pojedinačnoga ispravnog postupka i to isključivo radi obavijesti, a neuredna dostava ne sprječava daljnji postupak. ${ }^{7}$ Stoga dostava odluke o otvaranju pojedinačno ispravnog postupka ne utječe na postupak, budući da se dostava vrši samo radi obavijesti. 


\subsection{Dostava poziva za raspravu}

Iako je zemljišnoknjižni postupak strogo formalan postupak u kojem sud odluku donosi u redovnom postupku u pravilu bez održavanja rasprave, postoje i određene iznimke, pa se katkad provodi rasprava i u redovnom zemljišnoknjižnom postupku. ${ }^{8}$ Također, održavanje rasprave propisano je u gotovo svom posebnim zemljišnoknjižnim postupcima, Tako se kod postupka osnivanja obnove i dopune zemljišne knjige govori o raspravi za sastavljanje uložaka, ali ZZK-a ne obuhvaća odredbe o načinu dostave poziva na navedenu raspravu.

U praksi se pojavilo pitanje na koji način će se vršiti dostava poziva za raspravu bilo u redovnom ili u posebnim postupcima.

Dostava je propisana odredbama ZZK-a. Iako se u odredbama ZZK-a koje propisuju dostavu ${ }^{9}$ najprije govori o dostavi rješenja u zemljišnoknjižnom postupku, kasnije se govori i o dostavi pismena. Stoga smatramo da bi se i dostava poziva, kao i svih ostalih pismena u zemljišnoknjižnom postupku trebala obavljati sukladno s odredbama ZZK-a.

Osim toga, u zemljišnoknjižnom postupku provode se i ročišta u posebnim postupcima kao što su obnova, osnivanje i dopuna zemljišne knjige, ispravni i pojedinačni ispravni postupak i povezivanje zemljišne knjige i knjige položenih ugovora. Upravo u tim postupcima pitanje dostave važan je dio postupka koji utječe i na načelo učinkovitosti postupka.

Naime, u ispravnom postupku, kao i u pojedinačnom ispravnom postupku, prijave i prigovori raspravit će se pred zemljišnoknjižnim sudom (rasprava za ispravak). Raspravu za ispravak će, po proteku roka za ispravak, po službenoj dužnosti zakazati i provesti zemljišnoknjižni sud (u roku od 60 dana od objave oglasa) vezano za svaki zemljišnoknjižni uložak na koji je stavljena prijava ili prigovor, a u vezi sa

8 U redovnim postupcima rasprava se provodi u postupku ispravka pogrešnog upisa i opravdanja predbilježbe. Čl. 135. ZZK-a propisano je da se pogreška u upisu koja se uoči nakon provedenoga upisa, a čiji bi ispravak dovodio u pitanje već stečena prava i dovodio u opasnost osobe koje postupaju s povjerenjem u zemljišne knjige, može ispraviti na temelju rješenja o ispravku pogrešnoga upisa, donesenoga na temelju sporazuma svih zainteresiranih osoba u postupku pred zemljišnoknjižnim sudom za ispravak pogrešnoga upisa. U postupku za ispravak pogrešnoga upisa sud će saslušati sve zainteresirane osobe kako bi utvrdio mogućnost sporazumnoga ispravka. Iz navedene odredbe proizlazi da je nužno održati raspravu te na nju pozvati sve zainteresirane osobe. Raspravu za ispravak provodi i odlučuje sudac ili sudski savjetnik.

Čl. 68. st. 2. i 3. ZZK-a propisano je da će se prijedlog za brisanje predbilježbe odbiti ako nije priložena isprava iz stavka, a iz spisa kojim je dopušten upis predbilježbe vidljivo je da je tužba za opravdanje na vrijeme podnesena ili da rok za opravdanje još teče. Ako sud utvrdi da nisu ispunjene pretpostavke za odbijanje prijedloga, u kratkom će se roku održati ročište na kojem će dopustiti brisanje predbilježbe, ako osoba u čiju je korist predbilježba dopuštena ne dokaže da rok za opravdanje još teče ili da je podnijela tužbu na vrijeme. Raspravu za ispravak provodi i odlučuje sudac ili sudski savjetnik.

9 U čl 148. st. 1. ZZK-a se navodi kome se dostavlja rješenje u zemljišnoknjižnom postupku, kada se ono dostavlja, te na koju adresu. Međutim, već se u st. 4., 5. i 6. istoga čl. 138. ZZK-a govori o dostavi pismena, a čl. 139. ZZK-a također govori o dostavi pismena, a ne samo o dostavi rješenja. 
svim prijavama i prigovorima koji se odnose na njega. Iako ZZK obuhvaća odredbe o dostavi, u praksi kod posebnih zemljišnoknjižnih postupaka razvila se praksa da se pozivi za raspravu dostavljaju putem dostavljača suda ili katastra ili osobe od povjerenja.

U postupcima osnivanja i obnove zemljišne knjige provodi se rasprava, a $u$ ZZK-u se navodi tko provodi raspravu..$^{10}$ Tako ako sud primi obavijest o potvrđenom elaboratu katastarske izmjere ili tehničke reambulacije od tijela nadležnoga za katastar, postupak sastavljanja uložaka provest će se istodobno s izlaganjem na uvid podataka prikupljenih i obrađenih katastarskom izmjerom ili tehničkom reambulacijom. ${ }^{11}$ Upravo iz navedenih razloga, a imajući u vidu da ZZK u tom slučaju ne predviđa način dostave, dostava svim osobama izvršit će se na oglasnoj ploči ili putem osobe od povjerenja, sudskoga dostavljača ili na drugi prikladan način. Imajući u vidu odredbe ZZK-a o dostavi, autorica je mišljenja da one ne bi bile učinkovite u posebnim postupcima, već mogu dovesti do dugotrajnosti postupka.

U posebnim zemljišnoknjižnim postupcima u praksi se sve zainteresirane osobe pozivaju na raspravu i oglasom na oglasnoj ploči suda ali i na druge načine koji omogućuju javnost. Nenazočnost pozvanih osoba ne odgađa održavanje rasprave za ispravak niti znači da je nenazočna osoba povukla svoju prijavu ili prigovor, a niti da priznaje tuđe prijave ili prigovore.

\section{ELEKTRONIČKA DOSTAVA}

Elektronička dostava u zemljišnoknjižnom postupku predviđena je kao način dostave koji će u budućnosti biti osnovni način dostave pismena. Naime, po novom ZZK-u puno je toga predviđeno da se vodi elektroničkim putem. ${ }^{12}$ Novi je ZZK uveo elektroničku dostavu i to za jedan dio sudionika zemljišnoknjižnog postupka kao obvezu, dok je drugima dana mogućnost elektroničke dostave. Kao preduvjet elektroničke dostave nužno je ostvariti tehničke uvjete, a odluku o ostvarivanju tehničkih uvjeta donijet će ministar pravosuđa. Kod elektroničke dostave važno je utvrditi kada je dostava izvršena.

\subsection{Obveza elektroničke dostave}

Državno odvjetništvo kao ovlašteni korisnik informacijskog sustava podnosi prijedlog isključivo elektroničkim putem te se dostava pismena nadležnom državnom

10 Tako je u čl. 184. st. 2. i 3. ZZK-a propisano: „Raspravu za postupak sastavljanja uložaka, kao i sve radnje koje prethode raspravi za sastavljanje uložaka zemljišne knjige koja se osniva ili obnavlja može provoditi i zemljišnoknjižni referent bez posebnog ovlaštenja pod nadzorom ovlaštenog zemljišnoknjižnog referenta ili sudskog savjetnika. Rasprava za postupak sastavljanja uloška neće se provoditi kada su podaci zemljišne knjige istovjetni s podacima prikupljenim u katastarskoj izmjeri ili tehničkoj reambulaciji odnosno istovjetni s podacima postojećeg katastarskog operata koji je u službenoj uporabi.“.

11 V. čl. 185. ZZK-a.

12 Prema ZZK-u -u elektronički se vode zemljišne knjige, zbirka zemljišnoknjižnih rješenja, E-oglasna ploča, zbirka isprava, Z-spis, elektronička dostava, katastarski planovi (iz ZIS-a) te elektronički potpis. 
odvjetništvu također vrši isključivo elektroničkom putem. ${ }^{13}$ Navedena komunikacija suda i državnog odvjetništva u praksi u potpunosti funkcionira. ${ }^{14}$

ZZK je također propisao, ako je prijedlog podnesen elektroničkim putem, pismena zemljišnoknjižnog suda dostavit će se predlagatelju elektronički, a ostalim strankama elektroničkim putem ako su ispunjeni tehnički uvjeti. Dostava pravnim osobama vršit će se isključivo elektroničkim putem nakon što se ispune tehnički uvjeti, o tome odluku donosi ministar pravosuđa. Do sada ministar nije donio odluku ni za jedan zemljišnoknjižni sud da ispunjava sve uvjete za elektroničku dostavu. O rješenju suda nužnom za postupanje tijela nadležnoga za katastar, u granicama njegove nadležnosti, to se tijelo obavještava elektroničkim putem po službenoj dužnosti.

\subsection{Kada se smatra izvršenom elektronička dostava}

Ako se dostava vrši elektroničkim putem dostava se smatra izvršenom u trenutku zaprimanja pismena na poslužitelju predlagatelja. Riječ je o sistemskoj poruci o tome da je e-mail isporučen na poslužitelju (serveru) s datumom i vremenom. Na takvu poruku korisnik kojem se nešto šalje ne može utjecati, budući da je šalje poslužitelj izravno drugom poslužitelju koji je zatražio takvu obavijest pri slanju elektroničke pošte. Ta isporuka nije povezana sa stvarnim primanjem, uvidom ili čitanjem elektroničke pošte. Prema tome, nije odlučno kada je primatelj otvorio svoje računalo i vidio prispjelu poruku, već je odlučno kada je zabilježen primitak pismena na poslužitelju primatelja. Pri tome valja istaknuti da kod elektroničke dostave, ZZK drukčije uređuje kada se smatra dostava izvršenom od odredaba ZPP-a o elektroničkoj dostavi. ${ }^{15}$

Vezano za elektroničku dostavu ZZK, kao i Pravilnik o elektroničkom poslovanju korisnika i ovlaštenih korisnika sustava (dalje: Pravilnik), ${ }^{16}$ uveli su pojam ovlašteni korisnik informacijskog sustava. Tako je navedeno da je ovlašteni korisnik javni bilježnik, odvjetnik, a nadležno državno odvjetništvo kada je to potrebno u pripremi ili vođenju određenog sudskog ili upravnog postupka. Ovlašteni korisnici (javni bilježnici i odvjetnici) nisu punomoćnici stranaka. ${ }^{17}$

13 Čl. 105. st. 6. ZZK-a propisana je obveza nadležnog državnog odvjetništva da prijedlog podnosi elektroničkim putem. Državna odvjetništva prošla su edukaciju i u praksi se komunikacija između zemljišnoknjižnih sudova i državnih odvjetništva odvija isključivo elektroničkim putem.

14 No valja ukazati da ipak osnovna svrha takve dostave između zemljišnoknjižnog suda i nadležnog državnog odvjetništva nije u potpunosti ostvarena i to zbog slabe tehničke opremljenosti jednog dijela državnih odvjetništva. Na radionicama u organizaciji Pravosudne akademije na kojima su sudjelovalo zamjenici državnih odvjetnika i zemljišnoknjižni suci, zamjenici su ukazivali na staru i sporu opremu (računala i skenere) kojima raspolažu državna odvjetništva što znatno usporava rad i dostavu prijedloga s potrebnim prilozima sudovima.

15 Čl. 143.c. ZPP-a propisuje elektroničku dostavu u parničnom postupku. Tako je u st. 5. čl. 143. propisano da se dostava smatra izvršenom istekom 15 dana od dana kada je pismeno pristiglo u sigurni elektronički poštanski pretinac ako adresat $\mathrm{u}$ tom roku ne potvrdi primitak pismena.

16 Pravilnik o elektroničkom poslovanju korisnika i ovlaštenih korisnika sustava, Narodne novine, br. 108/19. (dalje: Pravilnik).

17 Čl. 4. Zakona o javnom bilježništvu, Narodne novine, br. 78/93., 29/94., 162/98., 16/07., 75/09., 120/16. (dalje: ZJB) propisano je kada je javni bilježnik punomoćnik stranke, dok je položaj odvjetnika kao punomoćnika stranke propisan odredbama Zakona o odvjetništvu, Narodne 
Ako javni bilježnik podnese prijedlog elektroničkim putem to ne predstavlja zastupanje stranke, već samo podnošenje prijedloga. Stoga se javni bilježnik ne treba upuštati u urednost prijedloga i sadržaj isprava i provjeravati ispunjavaju li isprave nužne pretpostavke za upis. U tom slučaju, iako je javni bilježnik podnio prijedlog elektroničkim putem, odluka se predlagatelju neće dostavljati elektronički. Podnositelju prijedloga neće se dostaviti rješenje suda elektroničkim putem, već će mu se odluka suda dostaviti pisanim putem, dok će se javnom bilježniku dostaviti rješenje, ali samo kao obavijest.

Kada javni bilježnik podnosi elektroničkim putem rješenje o nasljeđivanju, tada nije riječ o podnošenju prijedloga (što bi imalo za posljedicu i dostavu rješenja elektroničkim putem), već samo o dostavi rješenja radi provedbe. ${ }^{18}$

Odvjetnici mogu prijedloge slati kao punomoćnici stranaka, a mogu ih samo poslati, a da nisu punomoćnici stranaka, kada nisu sastavili prijedlog. Ako nisu punomoćnici stranke niti odvjetnici, nisu dužni provjeravati relevantne činjenice i pozivati stranke na dopunu prijedloga. Time se smanjuje odgovornost ovlaštenih korisnika kada prijedlog ne podnose kao punomoćnici stranka.

\section{DOSTAVA STAVLJANJEM NA OGLASNU PLOC̆U}

Objava pismena na sudskoj oglasnoj ploči rezervirana je za iznimne slučajeve kad su sudovi prethodno bezuspješno poduzeli sve što se od njih u konkretnom slučaju razumno moglo očekivati da pismeno doista dostave adresatu. Stoga se dostava na oglasnu ploču suda obavlja kada nije moguće uručiti naslovljenoj osobi (npr. „nepoznat”, „odselio”, „umro” i sl.), pismeno će vratiti sudu uz naznaku razloga zbog kojih ga nije moguće dostaviti. Ako je pismeno vraćeno s naznakom „nepoznat“ ili „odselio“, sud će pribaviti podatak iz evidencije MUP-a o adresi prebivališta odnosno boravišta. Ako je riječ o istoj adresi na kojoj je dostava prethodno ostala bezuspješna, sud će istekom roka od 30 dana od prethodne neuspjele dostave ponovno pribaviti podatak iz evidencije MUP-a o adresi prebivališta odnosno boravišta primatelja te mu pismeno dostaviti na tu adresu. Ako se ponovna dostava na adresu iz evidencije MUP-a ne uspije obaviti, pismeno će se objaviti na oglasnoj ploči suda. Ako MUP obavijesti sud da nema podataka o adresi primatelja, pismeno će se objaviti na oglasnoj ploči suda. Kad se pismeno vrati s naznakom da je primatelj pismena umro, a zemljišnoknjižni sud u roku od 60 dana od takvog saznanja nije primio obavijest o nasljednicima, pismeno će se objaviti na oglasnoj ploči suda. Smatrat će se da je dostava obavljena istekom 30 dana od dana stavljanja pismena na oglasnu ploču suda. Također i ako se ne može izvršiti dostava pravnoj osobi bilo na adresu iz prijedloga ili na adresu iz sudskog registra tada će se dostava izvršiti stavljanjem na oglasnu ploču suda.

Dostava putem oglasne ploče ima i svoj elektronički oblik jer je propisano da se oglasna ploča zemljišnoknjižnog suda vodi isključivo elektronički. Pritom valja imati na umu da se uz dostavu na e-oglasnu ploču suda veže početak rokova za mnoga

novine, br. 9/94., 117/08., 50/09., 75/09. i 18/11. (dalje: ZO).

18 U praksi javni bilježnici dostavljaju rješenja o nasljeđivanju na provedbu u elektroničkom obliku. Time je ubrzan postupak provođenja navedene odluke. 
prava koja stranke ostvaruju u zemljišnoknjižnom postupku. ${ }^{19}$ Međutim, e-oglasna ploča je za određeni dio građana nedostupna pa se postavlja pitanje omogućavanja/ onemogućavanja stranaka da zaštite svoja prava u zemljišnoknjižnom postupku.

\section{VAŽNOST IZVRŠENE DOSTAVE}

Zadaća je ovog rada ukazati da valjana dostava proizvodi određene pravne učinke. To se posebno odnosi na prava stranaka da izjavljivanjem pravnih lijekova odluke suda prvog stupnja podvrgavaju pravnoj kontroli i time osiguravaju zaštitu svojih prava. Također će se ukazati i na posebnost zemljišnoknjižnog postupka vezano za dostavu.

\subsection{Kako neuredna dostava utječe na provedbu odluka u zemljišnoknjižnom postupku}

Za zemljišnoknjižni postupak vrijedi jedna osobitost, a to je da činjenica da dostava nije uredno ili nije uopće izvršena ne daje prava osporavati valjanost knjižnoga upisa. Onaj koji iz knjižnoga upisa za sebe izvodi prava ili oslobođenja od obveze nije dužan dokazivati da je dostava izvršena. ${ }^{20}$ Takvom odredbom ne dolazi do onemogućavanja stranke, koja smatra da joj dostava nije uredno ili nije uopće izvršena, u ostvarivanju prava koja joj pripadaju u postupku, kao što bi to bio slučaj u parničnom ili drugom izvanparničnom postupku. Ta stranka svoja prava u zemljišnoknjižnom postupku može ostvarivati i u posebnom, parničnom postupku i to brisovnom tužbom, pa ako i nije uredno obaviještena o zemljišnoknjižnom postupku u kojem je došlo do upisa koji utječe na njezina knjižna prava, tada može svoja prava štititi u parničnom postupku.

Upisi u zemljišnu knjigu provode se prije dostave rješenja kojim se određuje upis i prije njegove pravomoćnosti. Žalba u zemljišnoknjižnom postupku nema suspenzivni karakter pa izjavljena žalba protiv rješenja o upisu ne odgađa njegovu provedbu. No, odluke u zemljišnoknjižnom postupku ne mogu postati pravomoćne ako nisu valjano dostavljene i ako nakon valjane dostave ne protekne rok propisan zakonom za izjavljivanje pravnog lijeka. Neovisno o tome što se rješenje u zemljišnoknjižnom postupku provodi prije njegove pravomoćnosti valjana dostava jedan je od preduvjeta za pravomoćno okončanje postupka.

$\mathrm{Uz}$ to, od trenutka dostave teku rokovi za izjavljivanje pravnih lijekova zemljišnoknjižnom postupku. ${ }^{21}$ Pravni lijekovi u zemljišnoknjižnom postupku su prigovor i žalba. Rok za izjavljivanje pravnog lijeka iznosi 15 dana i to od dana primitka rješenja. Imajući u vidu da se rješenja u zemljišnoknjižnim postupcima provode prije pravomoćnosti u praksi se katkad javljaju dvojbe o tijeku roka za žalbu, odnosno je li okolnost da je primatelj uvidom u zemljišne knjige saznao da je došlo do promjene vlasništva dostatna za računanje rokova za izjavljivanje pravnog lijeka

19 Tako u pojedinačno ispravnom postupku zainteresirane osobe mogu podnijeti svoju prijavu ili prigovor u roku od 30 dana od dana objave na e-oglasnoj ploči suda.

20 Čl. 142. ZZK.

21 Županijski sud u Velikoj Gorici, GžZk-374/2017-2 od 8. ožujka 2019. 
ili se taj rok isključivo računa od dostave odluke. Ovdje valja ukazati da se rok za izjavljivanje pravnog lijeka računa isključivo od dana uredne dostave pismena koje podliježe pravu na podnošenje pravnog lijeka. ${ }^{22}$

Vezano za dostavu u zemljišnoknjižnom postupku još valja ukazati da u tom postupku nije dopušteno tražiti povrat u prijašnje stanje zbog propuštenog roka za žalbu ili prigovor. ${ }^{23}$

\section{VRŠENJE DOSTAVE AKO JE PRIMATELJ U INOZEMSTVU}

ZZK-a ne obuhvaća odredbe o tome na koji način izvršiti dostavu ako se neka od osoba kojima po ZZK-a treba izvršiti dostavu ${ }^{24}$ rješenja nalazi u inozemstvu. Ako nema odredbi o dostavi u inozemstvo primjenjuju se odredbe izvanparničnog postupka, odnosno parničnog postupka. ${ }^{25}$ Pri tome se razlikuje situacija kada dostavu treba izvršiti u državu članicu Europske unije (dalje: EU) i u državu koja nije država članica EU.

22 Županijski sud u Velikoj Gorici, Gž Zk-369/2018-2 od 25. travnja 2019.: "S obzirom na žalbene navode predlagatelja gdje ističe da je činjenica dostave, odnosno nedostave pobijanog rješenja o upisu bespredmetna za ocjenu pravovremenosti prigovora Dragice Drešar te da je ona imala saznanja o postojanju rješenja o pobijanom upisu još 2011. kada je njezin sin kao tužitelj protiv Josipa Prstačića kao tuženika (ovdje žalitelja) podnio tužbu vezano uz predmetnu nekretninu pod poslovnim brojem P-928/16 te da je u tom postupku Dragica Drešar saslušana kao svjedok na ročištu 12. lipnja 2014. kada je iskazivala o pobijanom upisu, ovdje valja reći da ti žalbeni navodi nisu od utjecaja na pravilnost i zakonitost pobijanog prvostupanjskog rješenja. Ovo stoga jer rok za podnošenje pravnog lijeka teče od dana dostave rješenja o upisu, a ne od dana saznanja o upisu kako to pogrešno smatra žalitelj. No, kako je već naprijed navedeno, s obzirom da rješenje o upisu nije dostavljeno Dragici Drešar kao zakonskoj nasljednici prodavatelja tj. upisanog vlasnika, njezin prigovor protiv rješenja o upisu se ima smatrati pravovremenim.”.

23 Županijski sud u Velikoj Gorici a GžZk-218/2018-2 od 22. srpnja 2019.: „,...prema odredbi čl. 94. ZZK u zemljišnoknjižnom postupku, naime, nije dopušten povrat u prijašnje stanje. Na žalbene navode kojima se ukazuje na protuustavnost te zakonske odredbe treba odgovoriti da o suglasnosti zakona s Ustavom, temeljem čl. 125. al. 1. i čl. 126. st. 1. Ustava Republike Hrvatske („Narodne novine”, broj 56/90, 135/97, 113/00, 28/01, 76/10_i 5/14) odlučuje Ustavni sud.“.

Suprotno žalbenim navodima protustranke, prvostupanjski sud je pravilno ocijenio činjenice odlučne za pravovremenost predmetnog prigovora.

Kada je rješenje poslovni broj Z-22252/17 od 12. rujna 2017. protustranci ostavljeno u njenom poštanskom sandučiću 21. rujna 2017. s obzirom da se nije zatekla na adresi iz prijedloga (čl. 120. st. 4. ZZK) onda se prema odredbi čl. 120. st. 5. ZZK smatra da je dostava obavljena protekom roka od 30 dana od dana dostave rješenja ostavljenog u poštanskom sandučiću. Suprotno žalbenim navodima, za primjenu navedenih zakonskih odredaba, zakon nije kao zakonsku pretpostavku propisao obvezu da se takva dostava izvrši po određenom sudskom službeniku odnosno namješteniku (sudski dostavljač), već se navedene odredbe primjenjuju i u slučaju dostave preko pošte. U pogledu žalbenih navoda da se radi o neustavnim zakonskim odredbama, žalitelju se ponovno ukazuje da je za odlučivanje o tom pitanju isključivo nadležan Ustavni sud te da isto ne može biti predmet ovog žalbenog postupka.".

24 Osobe kojima se dostavlja rješenje u redovnom zemljišnoknjižnom postupku - čl. 138. ZZK-a i čl. 142. ZZK-a.

25 Čl. 99. st. 2. ZZK-a. 


\section{1. Što kada je predlagatelj u inozemstvu}

Predlagatelj koji se nalazi u inozemstvu, a nema opunomoćenika u Republici Hrvatskoj obvezan je već pri podnošenju prijedloga imenovati opunomoćenika za primanje pismena u Republici Hrvatskoj i naznačiti njegovu adresu. Ako prijedlog ne obuhvaća podatak o opunomoćeniku, sud će ga odbaciti. Dakle, ZZK-a je propisao posljedice ako predlagatelj koji se nalazi u inozemstvu ne imenuje opunomoćenika za primanje pismena. Pritom nije odlučno je li riječ o državljanima Republike Hrvatske koji imaju prebivalište (ili boravište) u inozemstvu ili je riječ o državljanima drugih država. Propisivanjem obveze imenovanja opunomoćenika za primanje pismena, ZZK-a je olakšao komunikaciju suda s predlagateljem. Naime, predlagatelju je uvijek nužno dostaviti odluku suda, bilo da se njegov prijedlog prihvaća i vrši upis ili da se njegov prijedlog odbija.

Pritom, sud može pozvati predlagatelja nepotpunoga prijedloga da dostavi isprave koje nisu tabularne isprave, ako je nedostatak takvih priloga jedina zapreka da se udovolji prijedlogu za upis. ${ }^{26}$

\subsection{Dostava u državama članicama Europske unije}

ZZK ne obuhvaća odredbe o dostavi kada se druge protustranke ili druge osobe kojima je nužno dostaviti rješenje nalaze u inozemstvu. Stoga ćemo reći nešto o dostavi u parničnom postupku.

Kod dostave u parničnom postupku razlikujemo dostavu u države članice EU te dostavu u druge države, izvan EU-a. Za dostavu sudskih i izvansudskih pismena u države članice EU-a obvezujuća je i izravno se primjenjuje u državama članicama EU-a Uredba broj 1393/2007 Europskog parlamenta i Vijeća od 13. studenog 2007. o dostavi u državama članicama, sudskih i izvansudskih pismena u građanskim i trgovačkim stvarima (dalje: Uredba o dostavi). Ovdje valja istaknuti da se ona ne primjenjuje u Danskoj. Ona je obvezujuća za sudove u Republici Hrvatskoj od pristupanja u EU-u. ${ }^{27}$

Prvo pitanje na koje je nužno odgovoriti je primjenjuje li se navedena Uredba u zemljišnoknjižnim predmetima. ${ }^{28}$

Kao i u svakoj primjeni uredbi EU-a, tako i u navedenoj Uredbi sudovi sve pojmove moraju tumačiti ne na način na koji ih tumače domaći pravni sustav, već kako te pojmove tumače sudovi EU-a, ${ }^{29}$ neovisno o njihovu značenju u našem domaćem pravu. Analizirajući praksu Suda Europske unije mišljenja smo da se navedena

26 Čl. 118. st. 8. ZZK-a.

27 Hrvatska je postala punopravna država članica EU 1. srpnja 2013.

28 Čl. 1. st. 1. Uredbe propisano je: „Uredba se primjenjuje u građanskim i trgovačkim predmetima gdje je potrebno iz jedne u drugu državu članicu dostaviti sudsko ili izvansudsko pismeno.“. Ne primjenjuje se na porezne, carinske i upravne predmete kao i na odgovornost države za radnje i propuste u izvršavanju javnih ovlasti (acta iure imperii).

29 Prema praksi Suda Europske unije sporovima građanske naravi ne smatraju se sporovi radi naknade štete protiv države iako je štetu počinio organ države ili osoba za koju država odgovara, bračni sporovi i sporovi u svezi s roditeljskom skrbi, nasljedni sporovi, insolvencijski te carinski i porezni sporovi. 
Uredba primjenjuje i na dostavu u zemljišnoknjižnim stvarima. Naime, od ulaska Republike Hrvatske u EU državljani država članica mogu stjecati, ali i prenositi prava na nekretninama (uz neke iznimke) ${ }^{30}$ istovjetno kao i državljani Republike Hrvatske. Tako se stranke koje imaju prebivalište, a time i adresu, izvan Republike Hrvatske mogu naći u pravnom položaju predlagatelja, ali i u pravnom položaju osobe kojoj treba dostaviti rješenje u inozemstvo.

Stoga za dostavu rješenja u zemljišnoknjižnom postupku, koja su donesena nakon stupanja Republike Hrvatske u punopravno članstvo EU valja primijeniti odredbe Uredbe o dostavi.

Da bi se dostava pismena mogla uputiti iz jedne države članice u drugu nužno je ispuniti određene uvjete.

Ponajprije da bi se pismeno moglo dostaviti u drugu državu članicu mora biti poznata adresa primatelja. ${ }^{31}$ Naime, u samoj Uredbi o dostavi propisano je da se Uredba ne primjenjuje ako nije poznata adresa primatelja.

Uz to, da bi se pismeno dostavilo podatci u pismenu moraju biti lako čitljivi, a zaprimljeno i otpremljeno pismeno moraju biti sadržajno istovjetni. Sudsko se pismeno šalje uz zahtjev koji je sastavljen na standardiziranom obrascu koji je svojim izgledom i sadržajem propisan Uredbom i njezin je sastavni dio. Uredba uređuje i pitanje jezika na kojem standardizirani obrazac mora biti ispunjen. Dostavu mora na temelju zahtjeva obaviti tijelo države članice prijema pa je kao načelo određeno da obrazac uz pismeno mora biti ispunjen na službenom jeziku države prijema. Pravilo o jeziku obrasca koji se dostavlja prijemnom mjestu uz pismeno ne odnosi se na pismeno koje se dostavlja, što znači da tijelo otpreme nije obvezno prevesti pismeno koje se dostavlja. Svaka država određuje je li to samo službeni jezik te države ili se ono može dostaviti i ne nekom drugom jeziku, dok su neke zemlje uz svoj službeni jezik odredile i neki drugi jezik. ${ }^{32}$

\subsubsection{Vršenje dostave}

Da bi se dostava sudskog pismena mogla izvršiti u drugu državu članicu, svaka od članica određuje ili službene osobe ili službena tijela ili druge osobe koje će biti nadležne za otpremu pismena, ako je takvu otpremu nužno izvršiti radi dostave pismena u drugoj državi članici EU-a. To su, tzv. „otpremna mjesta“.

Svaka država članica određuje službene osobe, tijela ili druge osobe koje su nadležne preuzeti pismena iz neke druge države članice i to su, tzv. ,prijemna mjesta“. Pritom, Uredba daje potpunu slobodu državama članicama prilikom određivanja

30 Primjerice, takva su ograničenja kod poljoprivrednoga zemljišta.

31 Čl. 1. st. 2. Uredbe propisano je da se Uredba ne primjenjuje ako nije poznata adresa osobe kojoj se pismeno mora dostaviti.

32 Republika Slovenija odredila je da se uz pismeno koje je potrebno dostaviti u Sloveniji mora priložiti obrazac na slovenskom jeziku, ali koji može biti i na engleskom jeziku. Tako ako bi sud Republike Hrvatske trebao dostaviti sudsko pismeno državljaninu Republike Slovenije koji se nalazi u toj državi, uz tužbu bi morao popuniti i propisan obrazac na slovenskom jeziku ili pak na engleskom jeziku. Ali, ako bi sud u Republici Sloveniji trebao izvršiti dostavu pismena hrvatskom državljaninu na teritoriju Republike Hrvatske, propisan obrazac uz pismeno mora biti ispunjen isključivo na hrvatskom jeziku. 
prijemnih i otpremnih mjesta. ${ }^{33}$

Republika Hrvatska je odredila da je otpremno mjesto radi slanja sudskih isprava svaki sud koji vrši dostavu dok je kao prijemna mjesta odredila općinske sudove na čijem bi području dostavu trebalo izvršiti.

Uredbom o dostavi svaka se država članica obvezuje odrediti jedno središnje mjesto koje će biti odgovorno za dostavu podataka o otpremnim mjestima i za rješavanje poteškoća koje bi mogle nastupiti kod otpreme pismena te u iznimnim situacijama takvo bi središnje mjesto bilo nadležno, na zahtjev otpremnog mjesta, proslijediti zahtjev nadležnom prijemnom mjestu, a u Republici Hrvatskoj središnje mjesto je Ministarstvo pravosuđa i uprave.

Kako smo mišljenja da se za dostavu odluka u zemljišnoknjižnom postupku primjenjuju odredbe Uredbe o dostavi to znači da ako bi se primatelj rješenja $u$ zemljišnoknjižnom postupku nalazio u inozemstvu, u jednoj od država članica Europske unije, zemljišnoknjižni sud u državi otpreme (Općinski sud koji je donio odluku u nekoj zemljišnoknjižnoj stvari) dostavlja rješenje sudu ili drugom tijelu države prijema koje je odgovorno za uručenje pismena, uz obrazac na jeziku koji je ta država odredila kao službeni jezik, time da rješenje nije potrebno prevoditi na taj jezik, a taj sud ili tijelo vrši dostavu primatelju po pravu države članice prijema. ${ }^{34}$ Iako tijelo otpreme nije obvezno sudsko pismeno prevesti na jezik države primateljice, pismeno mora biti sastavljeno ili na jeziku koji primatelj razumije ili na službenom jeziku države primateljice. ${ }^{35}$ Kako prijemno tijelo vrši dostavu po pravu države članice primateljice kao vrijeme dostave uzima se onaj dan kada je pismeno dostavljeno $\mathrm{u}$ skladu s pravom države članice primateljice.

Uredba o dostavi dopušta svaki oblik dostave između nadležnih tijela te se otprema pismena, potvrda, potvrda o primitku te drugih isprava između otpremnih i prijemnih mjesta između otpremnih i prijemnih mjesta može obavljati bilo kojim prikladnim sredstvom. ${ }^{36}$

Nakon što izvrši dostavu tijelo prijema o tim radnjama sastavlja posebnu ispravu na unaprijed određenom obrascu i takav obrazac šalje tijelu otpreme. ${ }^{37}$ Potvrda se sastavlja na službenom jeziku države članice otpreme ili eventualno na nekom drugom jeziku, ali samo ako je država otpreme navela da prihvaća njezino sastavljanje i na tom jeziku uz uvjet da mora biti riječ o jednom od službenih jezika EU-a. Republika Hrvatska izjavila je da prihvaća potvrde o dostavi samo ako su na hrvatskom jeziku.

$\mathrm{Na}$ kraju valja istaknuti da tek primitkom navedene potvrde države članice prijema zemljišnoknjižni sud ima valjanu dostavu i od datuma istaknutog na navedenoj

33 Državama članicama dopušteno je, umjesto određivanja više prijemnih ili otpremnih mjesta, odrediti jedno otpremno ili prijemno mjesto ili čak jedno tijelo koje bi obavljalo obje dužnosti.

34 Čl. 7. Uredbe o dostavi.

35 Naime čl. 5. st. 1. Uredbe o dostavi propisano je da adresat može odbiti prijem jer pismeno nije sastavljeno na odgovarajućem jeziku ili barem ako nije prevedeno na odgovarajući jezik. Pravo na odbijanje primitka ili pravo na vraćanje pismena otpremnom mjestu imati će primatelj ako pismeno nije sastavljeno na jeziku koji primatelj razumije ili na službenom jeziku države članice prijema.

36 Čl. 4. st 2. i 3. Uredbe o dostavi.

37 Čl. 4. st. 5. Uredbe o dostavi. 
potvrdi teče rok za izjavljivanje pravnog lijeka.

U praksi je primijećeno da se velik broj pismena u zemljišnoknjižnom postupku dostavlja bez primjene navedene Uredbe o dostavi s „narančastom dostavnicom”. Mišljenja smo da takva dostava ne bi bila valjana te da bi sudska pismena valjalo u države članice EU dostavljati primjenom odredbi navedene Uredbe o dostavi.

\subsection{Dostava u države koje nisu članice Europske unije}

U zemljišnim knjigama u našoj zemlji, zbog povijesne povezanosti, dolazi upisan znatan broj osoba koje su državljani drugih zemalja, a ne država članica EU. Te se osobe češće javljaju kao osobe kojima je odluku potrebno dostaviti, a rjeđe kao predlagatelji, stoga se postavlja pitanje kako izvršiti dostavu pismena navedenim osobama.

Način dostave pismena u pojedine države koje nisu članice EU-a uređen je međunarodnim ugovorima i konvencijama. Tako se dostava sudskih pismena u Bosnu i Hercegovinu vrši na temelju Sporazuma između Vlade Republike Hrvatske, Vlade BiH i Vlade Federacije BiH o pravnoj pomoći u građanskim i kaznenim stvarima od 26. veljače 1996. ${ }^{38}$ i Sporazuma između Republike Hrvatske i BiH o izmjeni Sporazuma između Vlade Republike Hrvatske, Vlade BiH i Vlade Federacije BiH o pravnoj pomoći u građanskim i kaznenim stvarima od 17. lipnja 2002. (dalje: Sporazum BiH). ${ }^{39}$

Dostava u Sjevernu Makedoniju vrši se na temelju Ugovora između Republike Hrvatske i Republike Makedonije o pravnoj pomoći u građanskim i kaznenim stvarima od 2. rujna $1994 .^{40}$

Dostava u Srbiju i Crnu Goru vrši se na temelju Ugovora između Republike Hrvatske i Savezne Republike Jugoslavije o pravnoj pomoći u građanskim i kaznenim stvarima (Srbija i Crna Gora) od 15. rujna 1997. ${ }^{41}$

Dostava u Sjedinjene Američke Države vrši se prema pravilima Haške konvencije o dostavi u inozemstvo sudskih i izvansudskih dokumenata u građanskim i trgovačkim stvarima od 15. studenoga 1965. (dalje: Haška konvencija o dostavi). ${ }^{42}$

38 Zakon o potvrđivanju Sporazuma između Republike Hrvatske i Bosne i Hercegovine o izmjeni Sporazuma između Vlade Republike Hrvatske, Vlade Bosne i Hercegovine i Vlade Federacije Bosne i Hercegovine o pravnoj pomoći u građanskim i kaznenim stvarima, Narodne novine međunarodni ugovori, br. 5/03.

39 Sporazum između Vlade Republike Hrvatske, Vlade Bosne i Hercegovine i Vlade Federacije Bosne i Hercegovine o pravnoj pomoći u građanskim i kaznenim stvarima, Narodne novine - Međunarodni ugovori, br. 12/96., stupio na snagu 20. prosinca 1996., Narodne novine Međunarodni ugovori, br. 3/08.

40 Ugovor između Republike Hrvatske i Republike Makedonije o pravnoj pomoći u građanskim i kaznenim stvarima, potpisan 2. rujna 1994. u Skopju, Narodne novine - međunarodni ugovori, br. 3/95., stupio na snagu 29. svibnja 1995., Narodne novine - međunarodni ugovori br. 1/97.

41 Ugovor između Republike Hrvatske i Savezne Republike Jugoslavije o pravnoj pomoći u građanskim i kaznenim stvarima, sklopljen u Beogradu 15. rujna 1997., Narodne novine - međunarodni ugovori, br. 6/98., stupio na snagu 28. svibnja 1998., Narodne novine Međunarodni ugovori, br. 8/98.

42 Haška konvencija o dostavi u inozemstvo sudskih i izvansudskih dokumenata u građanskim i trgovačkim stvarima od 15. studenoga 1965., Narodne Novine - Međunarodni ugovori, br. 
Kao novo pitanje javlja se dostava u Ujedinjeno Kraljevstvo koje je s 1. siječnjem 2021. prestalo biti državom članicom EU-a. Vezano za dostavu u Ujedinjeno Kraljevstvo Ministarstvo pravosuđa i uprave poslalo je dopis ${ }^{43}$ kojim je upoznalo sudove da će se zahtjevi za dostavu poslani u skladu s Uredbom o dostavi do 31. prosinca 2020. obrađivati, dok će zahtjevi poslani za uručenje sudskih pismena po Uredbi o dostavi nakon 1. siječnja 2012. biti vraćeni tijelu koje je taj zahtjev i otpremilo. Zahtjevi za dostavom pismena nakon 1. siječnja 2021. vršit će s primjenom Haške konvencije o dostavi uz upotrebu obrazaca te formi zahtjeva propisanih navedenom Konvencijom.

\section{UMJESTO ZAKLJUČKA}

Uredna dostava zauzima važno mjesto i u zemljišnoknjižnim postupcima, neovisno od posebnosti dostave u zemljišnoknjižnim postupcima. Naime, ta se posebnost ogleda u tome da se provedba upisa obavlja prije pravomoćnosti rješenja o upisu, pa i prije njegove dostave strankama. Učinkovitost dostave s jedne strane pruža sigurnost da je pismeno upućeno primatelju zaista i stiglo u njegove ruke. S druge strane, ta je sigurnost dostave važan preduvjet ostvarivanja prava na izjavljivanje pravnih lijekova. Posljedica je izostanka uredne dostave onemogućavanje stranaka da ostvaruju svoja Ustavom zajamčena prava na izjavljivanje pravnih lijekova, odnosno onemogućavanje stranaka da štite svoja prava i interesa.

\section{LITERATURA}

1. Bulka, Zinka. Novi zakon o zemljišnim knjigama (priručnik za polaznike). Zagreb: Pravosudna akademija, 2019. https://www.pak.hr.

2. Haška konvencija o dostavi u inozemstvo sudskih i izvansudskih dokumenata u građanskim i trgovačkim stvarima od 15. studenoga 1965., Narodne Novine - međunarodni ugovori, br. $10 / 05$.

3. Milaković, Goran. „Nova pravila dostave u zemljišnoknjižnom postupku s osvrtom na dostavu elektroničkim putem“. Javni bilježnik 39 br. 14 (2014): 71-80.

4. Pravilnik o elektroničkom poslovanju korisnika i ovlaštenih korisnika sustava, Narodne novine, br. 108/19.

5. Pravilnik o unutarnjem ustrojstvu, vođenju zemljišnih knjiga i obavljanju drugih poslova u zemljišnoknjižnim odjelima sudova, Narodne novine, br. 81/97., 109/02., 123/02., 153/02., 14/05., 60/10., 55/13., 60/13. i 63/19.

6. Sesa, Đuro, Dragan Katić. Dostava izvan Republike Hrvatske (priručnik za polaznike). Zagreb: Pravosudna akademija, 2018. https://www.pak.hr.

7. Ugovor između Republike Hrvatske i Savezne Republike Jugoslavije o pravnoj pomoći u građanskim i kaznenim stvarima, Narodne novine - međunarodni ugovori, br. 6/98.

8. Uredba broj 1393/2007 Europskog parlamenta i Vijeća od 13. studenog 2007. o dostavi u državama članicama, sudskih i izvansudskih pismena u građanskim i trgovačkim stvarima. https://eur-lex.europa.eu.

9. Zakon o načinu primjene pravnih propisa donesenih prije 6. travnja 1941. godine, Narodne novine, br. $73 / 91$.

$10 / 05$.

43 Dopis Ministarstva uprave i pravosuđa, Uprave za europske poslove, međunarodnu pravosudnu suradnju i sprječavanje korupcije, klasa: 910-02/20-01/31, urbroj: 514-07-02-02/3-20-04 od 28. prosinca 2020. 
10. Zakon o parničnom postupku, Narodne novine, br. 53/91., 91/92., 112/99., 88/01., 117/03., 2/07., 84/08., 96/08., 123/08., 57/11., 148/11., 25/13., 28/13., 89/14. i 70/19.

11. Zakon o potvrđivanju Sporazuma između Republike Hrvatske i Bosne i Hercegovine o izmjeni Sporazuma između Vlade Republike Hrvatske, Vlade Bosne i Hercegovine i Vlade Federacije Bosne i Hercegovine o pravnoj pomoći u građanskim i kaznenim stvarima, Narodne novine -međunarodni ugovori, br. 5/03.

12. Zakon o zemljišnim knjigama, Narodne novine, br. 63/19.

13. Županijski sud u Velikoj Gorici, Gž Zk-218/2018-2 od 22. srpnja 2019.

14. Županijski sud u Velikoj Gorici, Gž Zk-369/2018-2 od 25. travnja 2019.

15. Županijski sud u Velikoj Gorici, GžZk-374/2017-2 od 8. ožujka 2019. 


\section{Zinka Bulka*}

Summary

\section{DELIVERY OF DOCUMENTS IN THE LAND REGISTRATION PROCEDURE}

The paper gives an overview of the provisions of the Land Registry Act that regulate the delivery of documents in the procedure. The emphasis is on peculiarities and shortcomings of the land registry procedure regarding delivery of the ruling on entry, as well as summons and other documents. Special attention is paid to the delivery outside the Republic of Croatia, with an emphasis on delivery to EU Member States, but also delivery to other countries, especially neighboring countries and United Kingdom in view of Brexit.

Keywords: delivery; types and importance of delivery; address of the recipient; delivery abroad.

* Zinka Bulka, dipl. iur., Judge of County Court in Velika Gorica; zinka.bulka@svg.pravosudje. hr. ORCID: https://orcid.org/0000-0002-7120-4313. 
